С. Є. Ігнатьєва

\title{
ЛЕКСИКО-СЕМАНТИЧНА РЕПРЕЗЕНТАЦІЯ МОДЕЛІ «ПАМ'ЯТЬ» В УКРАЇНСЬКОМУ ЩОДЕННИКОВОМУ ДИСКУРСІ
}

\footnotetext{
Ігнатьєва С. Є. Лексико-семантична репрезентація моделі «пам'ять» в українському щоденниковому дискурсі.

У статті на матеріалі українського щоденникового дискурсу репрезентовано кореляцію когнітивних процесів пам'яті, виявлено модель пам'яті в аксіологічному аспекті, визначене місце їі локалізації. Також проаналізовано фрейми та предикати пам'яті.

Ключові слова: модель, пам'ять, види пам'яті, предикати пам'яті, метафори, український щоденниковий дискурс.

Игнатьева С. Е. Лексико-семантическая репрезентация модели «память» в украинском дневниковом дискурсе.

В статье на материале украинского дневникового дискурса репрезентирована кореляция когнитивных процес сов памяти, выявлена модель памяти в аксиологическом аспекте, определено место ее локализации. Также проанализированы фреймы на предикаты памяти.

Ключевые слова: модель, память, виды памяти, предикаты памяти, украинский дневниковый дискурс.
}

Ignatyeva S. Ye. The lexical-semantic meaning of the model «memory» in Ukrainian diary discourse.

The article represents the correlation of cognitive processes of memory on the materials of Ukrainian diary discourse. There was revealed the model of memory in accilological aspect and pointed out the place of its localization. There was also analyzed frames and predicates of the memory. discourse.

Key words: model, memory, kinds of memory, predicats of memory, metaphors, Ukrainian diary

Особливістю щоденникового дискурсу (ЩД) є те, що в основі його формування знаходяться когнітивні механізми пам'яті - психічне відображення взаємодії людини 3 дійсністю у минулому, асоціативне пригадування образів, здатність зберігати інформацію і вибірково піi актуалізувати, співвідносити епізодичну і семантичну пам'ять. Предметом зображення у ЩД є минуле через становлення внутрішнього світу його автора. На нашу думку, у ЩД є три головних «герої»: швидкоплинний час, який автор намагається зупинити, його власне «я», повнота розкриття 
якого може бути різною, i пам'ять, яка зберігає світ минулого i понадчасову єдність i тотожність «я». Пам’ять - процеси запам'ятовування, збереження, відтворення i забування індивідом свого досвіду. Вона становить складову пізнавальної діяльності людини. Завдяки пам'яті людина у формі знання привласнює досягнення попередніх поколінь, оволодіває продуктами культури. Людська пам'ять, таким чином, слугує ланкою зв'язку між минулим, теперішнім і майбутнім. Утрачаючи пам'ять, людина губить не лише своє минуле, а й здатність нормально жити. Пам'ять становить основу життя. Як зауважує Петро Сорока: «Сдине, щзо не старіє - спогади, мемуари, чи не тому, щзо за своєю природою, за жанром вони приречені переборювати час, вони саме переборення часу» [10, с. 106]. Ми розглядаємо пам'ять як ланцюжок між активним зв'язком людини i світом. Саме пам'ять в українському щоденниковому дискурсі є об'єктом нашого дослідження. Предмет дослідження - модель пам'яті в аксіологічному аспекті. На думку Олени Селіванової, «Пам’ять - когнітивна здатність утримувати й систематизовано інтегрувати в мозку людини різнобічну інформацію, отриману в результаті переробки чуттєвого та внутрішнього рефлективного досвіду. Пам'ять опосередковує набуття, організацію та збереження знань - інформації, наявної в мисленні людини, що служить для розв'язання нею інтелектуальних і мовних завдань, застосовується в повсякденній пізнавальній і мовленнєвій діяльності, зумовлює поведінку людини» [7, с. 527].

Словосполучення 3 семою «nам'ять» в ЩД $є$ сигналами на так звану «щоденникову орієнтацію». Пам’ять має образну характеристику за рахунок використання загальномовних метафор, наприклад, пам'ять механізм, записний пристрій. Вона може міцуно сидіти в мені, закарбовуватися в сериі, триматися в голові, ввібрати в душу побачене, запасти в душу, залишитися на душі, зберегтися в пам'яті, відбиватися у душі, врізатися у свідомість, глибоко запасти у душу, запектися у душі, міцно врізатися у свідоміст, носити у пам'яті, наповнювати радістю криницюю душі, лягати на душу як тиха молитва, оживати в пам'яті тощо. Пам'ять може стиратися, викреслювати, залишатися: 3 сотні прочитаних книг у пам'яті залишається одна. Про решту за тиждень уже й не згадаєш, а за місяџь забудеш їх назви та імена авторів [9, с. 147]; Час від часу я різьблю дерево чи витесую щуось із каменю. Найчастіше не виходить нічого доброго $i$ я знищую роботу. Але щцсь незнищенне залишається в душі [9, с. 166]. А ще вона ...залишається записаною у небі [11, с. 117]. Проте водночас думки, як і люди, можуть помирати: Думки помирають, як і люди, як і усе на цььому світі. Але ми спроможні продовжити їх життя, якщзо упіймаємо та закарбуємо на папері. При цуьому вони щуось, звичайно, втрачають, як метелики, нанизані на шпильки. І все ж.Тобто: пишеш не діяріюш, а прагнеш упіймати думку [11, с. 44]. 
Визначимо місце збереження пам'яті. Вона, як і все інтелектуальне життя людини, локалізується: a) у голові, на що вказують такі висловлювання, як тримати у голові, вилетіло з голови, викинути $з$ голови, приходить у голову тощо: Коли я дивлюсь на портрети ... мені приходить у голову багато сумних думок. Керувати на кінозйомках масовиками уміє далеко не всякий режисер[4, с. 261]; Але все далеко не так, як у дитинстві. Не так. Чому? Чи не тому, щзо жив тоді за межами часу, а mепер він постійно тримає мене у своїх лещзатах? Я начебто відпочиваю, але в голові тримаю те, щзо повинен зробити через годину, завтра і через тиждень [8, с.64];

б) у душі, на що вказують такі висловлювання, як залишити у душі, залишили на душі, відбитися у душі, ввібрати у душу, збуджсвати у душі тощо: Знав, щзо піснею можна торкнутися таких струн душі, яких мовлене слово навряд чи торкнеться. Запав мені той спів глибоко в душу... [8, с. 83]; Все ж у душі відбувасться щцось неймовірно потужне, а робота мислі не припиняеться ні на мить [8, с. 46]; Сяйво пісні, сяйво свята залишили на душі [3, т. 1, с. 308]. Хіба раніше, за молодих літ, я вдивлявся так пильно у красу природи? Хіба цей світ так зачаровував мене? Здається, шуо ні, все пролітало якось мимо, мимо. I тільки відсвіт того золотого сяйва відбивався у душі, не зачіпаючи їі глибинно [8, с. 46]; Тепер просто впиваюся красотами землі. Особливо осінню. Ніби хочу ввібрати в душу все побачене, щиоб пронести з собою у засвіти [8, с. 47]; Пригадую перший його (Євгена Гуцуала) вірш, щзо потрапив мені на очі десь наприкінці сімдесятих, одраз жс глибоко запав у душу...[10, с. 11]; Це не легкі літні чи зимові дими, щуо одразу ж линуть до небес, не збуджсуючи в душі жсодих почуттів, не викликаючи $і$ не залишаючи в ній нічого сталого. Це дими вічності [11, с. 100]

в) у душі і пам'яті: Найкраще мандрувати пішки. Путопаш. Нагріту землю відчувати босими ногами $i$...ерцеем. Оді більше залишається в душі й пам'яті...[9, с. 51]; Те, щуо відбувається навколо, має неперебутнє значення, все хочеться увібрати в душу, запам'ятати, зберегти у пам'яті ...[9, с. 37]; Уэе в самому звучанні назв українських міст мені вчувається голос їх душі і пам'ять минувшини: Ніжин, Батурин, Черкаси, Корсунь, Бар, Бердичів, Лубні... [11, с. 80]; 3міст майжсе забувся, але зберігся в пам'яті той дивний хвилюючий настрій, який вони навіяли. І изе головне. Бо ж тільки вічне западає в душу, те, шуо написане кров'ю, сльозою перемите [9, с. 189];

г) у серці: Та закопала глибоко в серці страшну таємницую - $i$ від Мазепи, і від чоловіка [11, с. 29]; Невибагливий, але безконечно милий краєвид рідного Жукова. Щось піднімається у душі тепле і хвилююче, коли любуюся ним. I дорогий він мені у різні пори року. Розкрилля степу на сході i бовваніючи у сонячній ясі могили, звивиста стрічка дороги, щзо зникає за овидом, одинокі дерева у полі, сповнені туги і дивовижного спокою, високі 
темні тополі, щзо вибігли за хутір, гін піль заходу, щзо добігають найближчих хуторів Луб'янок $i$ Чагарів, - усе навіки в серці. Усе заберу 3 собою у засвіти [11, с. 137];

г) у свідомості: Біля домовини товпилося багато людей, але всі вони якось зодманітнились та зчужіли, й тільки стемнілий профіль Ярослава Павуляка болісно врізався у свідомість [10, с. 11];

д) у серці, мозкових клітинах, шкірі, а ще запеклій крові: Мабуть, є пам'ять серця, пам'ять мозкових клітин, дуиі і навіть икіри. Батурин - це пам'ять моєї запеклої крові. Я пойхав туди, стурбований долею Любові й Мотрі, $i$ те, щчо побачив не просто вжахнуло мене (чи мало бачив на своєму віку звірств $і$ людських трупів? Цілі поля були ними встелені під Корсунем та Жовтими водами), та вид спаленого Батурина убив мою віру в людину. Від розкішної $і$ величної гетьманської столиці залишилося одне згарище... Спалили усе: замки, палаци, майстерні і убогі міщанські халупи... Земля почорніла од крові, скрізь виблискували на вогні зловіщі калюжсі... Крики, зойки, прокляття $і$ стогони чулися звідусіль... [11, с. 98]. Отже, на нашу думку, у національній моделі людини місцем локалізації пам'яті $\epsilon$, голова, душа, серце, свідомість, мозкові клітини, шкіра, а ще запекла кров. Найактивнішим місцем для локалізації пам'яті все ж $є$ душа.

Однією із найпродуктивніших метафоричних моделей ЩД є модель «пам'ять». Метафори пам'яті створюють своєрідний метафоричний скелет ЩД. У межах цієї моделі виділяються такі своєрідні фрейми:

- «Мати перед очима»; «перед очима стояти»: Завериується відміряний тобі долею шлях. Бачив краӥни Заходу і Сходу, бував по цей $і$ по той бік екватора. Маю перед очима досить повний образ планети. Що більше відкривалось мені, то більше вражала ї̈ мініатюрність, незахищеність перед безвістями космічного холоду. I не перестає тебе дивувати изе чудо, чудо життя, щуо летить у безвістях...[3, т. 3, с. 26]; Умене перед очима стоять привиди - київські звільнені з неволі громадяни, живі меризі [4, с. 312]; У важкі хвилини, коли здавалося, вистояти неможливо, перед моїми очима завжди зринали літературні герої і додавали нових сил [10, с. 124];

- «вертатися думками»: Що зі мною діється? Що не роблю, куди не йду, знов $і$ знов вертаюсь думками до одного: щуо буде з людьми? $[3$, т. 3, с. 50];

- «постати перед нею»: Може, є щуось у житті таке, до чого людина й не повинна повертатись вдруге? Щоб чари не розвіялись, щуоб не обуденилось те, щзо - вперше і востаннє - постало перед нею, як образ краси найвищої, божественної? [3, т. 3, с. 50];

- «зостатися в душі»: Ось так $і$ ия азовська «степова Еллада» хай зостанеться в душі поетичним і прекрасним видінням, чимось фантастичним, де і небо, і люди, і птахи - все було не таке, як скрізь... [3, т. 3, с. 50]; 
- «політати думками понад бідною Україною»: Поговорив сьогодні з Крижанівським, політав думками понад бідною Украӥною, $i$ так мені стало сумно, так тужно, щзо й сказати собі не можу... $[4$, c. 257];

- «озватися звідти, з дитинства, юності»: Бачимо зиму нарешті: тверду, снігову, морозну. І з нею щось ніби озвалося звідти, з дитинства ... [3, т. 1, с. 309]; Голос із юності (лист) [3, т. 3, с. 73];

- «не запектися в душі»: Але ие не надломило його і не запеклося в душі образливою чорнотою, а ще ніби більще випрозорило й вибілило ї̈ $[9$, c. 53];

- «міцно врізатися в пам'ять»: Всі вони міцно врізалися в мою пам'ять - моє щастя залежало від їх ставлення, сумлінності та добросовісності [9, с. 17];

- «увібрати в душу, запам'ятати, зберегти у пам'яті»: Те, щэо відбувається навколо, має неперебутнє значення, все хочеться увібрати в душу, запам'ятати, зберегти у пам'яті [9, с. 37];

- «міцно сидіми»: ... в мені міцно сидить усвідомлення того, що $\epsilon$ багато людей, яким у ией час незрівнянно важче, які конають на лікарняних чи тюремних нарах, на чужині чи вулиці [8, с. 43];

- «закарбуватися в серці»: На жаль, досі я мало знав творчість В. Сологуба, тільки дещо читав у «ЛУ», але це закарбувалося в серці. Наприклад, новела про А. Малишка, Д. Яворницького [9, с. 189];

- «не дати забути»: Я знаю те жахіття, що приносить біль. Вісім років він наступає мені на п'яти, жать, як змія, несподівано і підступно у будь-яку пору чи ночі, не дає мені забути, що він моя тінь і разом з ним назириі за мною ходить смерть [9, с. 65];

- «спливати у пам'яті»: Але думка праџюе $і$ я ще контролюю свої відчуття. У пам'яті спливає остання фраза Юрка Гудзя, почута від нього при прощанні: «Колись ітиму, як ми зараз, упаду - і помру» [8, с. 48];

- «зринати 3 глибин пам'яті»: Голос Мазепи зринає 3 глибин пам'яті, ніби з недовідомої даличини, а ще ніби передучора слухав його псальми... [11, с. 122];

- «пропливати перед очима»: ...i Московія з ї̈ величезними просторами пропливала перед моӥми очима [11, с. 100]; Пити очима красу - наповнювати радістю криницю душі [11, с. 35];

- «змигнути у пам'яті»: Змигнуло у пам'яті: у давній статті Ігоря Герету якось зазначив: важливо як пишемо і підходимо до слова: чи як до святині, перд якою в німому зачудуванні зупиняється душа, чи як до предмета гри [10, с. 80];

- «лягати на душу як тиха молитва»: Така дивна $і$ світла краса Мотрина, що кожне ї̈ слово звучить і лягає на душу як тиха молитва [11, с. 36]; - «оживати в пам'яті»: Озираюся у минуле $i$ воно оживає в пам'яті окремими яскравими епізодами. Багато чого забулося, ๑ С. Є. Ігнатьєва, 2011. 
вивітрилося назавжди і його уже ніколи не ожниити у вигасаючому мозку...Ми їхали сповнені надій і сподівань. Стояв гарячий червенв. Все пахло і квітло навкруги і п'янило душу... [11, с. 62];

- «не вмерти у мені»: Степ мучить мене своєю красою, своїм чаром. Ще одне не вмерло у мені - иял любов до вільного розкрилля. Тихого шепоту тирси, розкішного буяння червоного воронцую, білопіння ромашки $i$ блакитних спалахів блаватів... [11, с. 155];

- «зберегти хвилюючі таємниці»: $C$ ріки, щуо зачаровують 3 першого погляду, є такі, щзо вбирають зір $і$ від них важко відвести очі, $i$ такі, щзо зберігають хвилюючі романтичні таємниці, а ияя (Волга) страшні [11, с. 100$]$;

- «Скресають згадки»: Скресають згадки про Мазепу... $i$ вкриваються вечоровою мрякою. Усе зникло $і$ пропало. Нема нічого. I більше не буде... [11, с. 157].

Як бачимо, метафоричні фрейми беруть активну участь у формуванні моделі «пам'ять», яка $\epsilon$ важливим складником українського щоденникового дискурсу. Вони мають широкий діапазон щодо форм свого вираження. Також ці метафоричні фрейми пов'язані з приписуванням об'єкту невластивої йому семантики і реалізуються в різних типах метафоричних словосполучень. Спільна смислова структура метафори дозволяє авторам ЩД варіювати формальне вираження поняття, що слугує запорукою розвитку метафори у щоденниковому дискурсі. Ці особливі побудови, що відхиляються від звичайного синтаксичного типу дають оригінальну форму для вираження думок і почувань автора.

Пам'ять у ЩД є неохопною, непощербною, незатертою, проте 3 часом вона починає пригасати або навпаки озиватися: Яка неохопна пам'ять була в моєї сестри. Як у того героя Ірвіна Шоу-Форстера із оповідання «Сонячний берег річки Лети». Вона пам'ятала все, щуо будьколи почула чи прочитала, більще - почула, бо читати не любила і досі не любить. Ця пам'ять добре служила їй піввіку, а тепер починає пригасати. Як свічечка, щцо вигоріла. Я, на жаль, не міг змагатися з нею, хоча мені теж дістався якийсь одламок того дару [10, с. 95]; Чи забуті ті пам'ятні розмови про душу, спасіння, по загробне життя? Не зважаючи на їі похилий вік (була старшою од мене на два з половиною десятки літ), виглядала ще досить бадьорою, вражала свіжістю суджень, глибиною розуму і непощербною пам'яттю... При тому гостро відчувалося, щзо ие жінка великої душі й рідкісного серия [11, с. 1]; У дитинстві вогонь викликав у мене майже містичний жах: підсвідомо відчував, щуо він посланецьь з тогосвітня. Чи це озивалася незатерта пам'ять? Поступово прийшла любов до вогню...[11, с. 1];

А ще згадувати можна повільно - повзком : Здається, тільки раз чи двічі він повзком згадав свою дружину Ганну Половець, доньку білочерківського полковника Семена Половця, з якою прожив усього кілька 
років [11, с. 78] і швидко, блискавично: Зимою часу нема, хоч іноді день може тягнутися нескінченно довго, а безсонна ніч стали вічністю. Та коли вони минуть, то згадуються як одна хвилина. Велика загадка часу, який так $\epsilon$, ніби його немає [11, с. 137]. Можна довго пам'ятати про щось незабутнє: Скільки пам'ятаю, вона завжди жила самотою [10, с. 63], а можна швидко про все забувати: Потужила за ним якийсь час - $\boldsymbol{i}$ забула [11, с. 22 ]; Швидко забувається [9, с. 209]. Проте, щуоб зберегти ясність думки $\boldsymbol{i}$ здоровий глузд треба думати про красу світу $i$ добро, щөо $\epsilon$ в ньому, а не терзатися розмислами про зло і людські вади [10, с. 125].

Ураховуючи характер репрезентованого матеріалу, час його збереження та ступінь опосередкованості механізмів, у щоденниковому дискурсі виділяємо такі види пам'яті:

a) емоційна пам'ять, яка надає можливість зберігати його автору емоції та почуття. Завдяки предметності почуттів - віднесеності до ситуації, що їх викликала, змістом емоційної пам'яті є не самі по собі почуття, а емоційно забарвлені події, які відбувалися у минулому. Краще за все утримується в пам'яті сильні і значні фізичні подразники (посвисm бомб, світло яскравого прожектора, здригання будинку, дзенькім розбитих шибок тощо): Згадую найсильніші моменти хвилювання: коли бомбували Харків, а я мимоволі залишився в хаті, бо через переслідування агентури не міг з'являтися на людях, і повітряною хвилею розчинило двері з галереї та сильно кинуло мене в коритар і потовкло бачу крізь шкло галереї сонячний день, чую посвист бомб, вибухи $\boldsymbol{i}$ здригання будинку $\boldsymbol{i}$ дзенькіт розбитих иибок, помічаю, як сонце заслонили вже руді пасма пороху від вибухів, $i$ думаю: отак має виглядати кінець світу [5, с. 147], або: Оживає минуле і, ніби озиваються засвіти, дзвін шабель і гул гармат, голоси тих, що давно відійшли у засвіти... Скільки пережито скільки звідано! Повертаюся в минуле і відчваю, що не було у мене більшого щуастя, як от оце умиротворююче любомудріс до зорі [11, с. 47].

Отже, запам'ятовується те, що насамперед збуджує емоції. Окрім того, емоційній пам'яті притаманна міцність: глибоко пережиті, особливо неприємні, події важко забути: Чомусь врізалася в пам'ять зсутулена постать Миколи Литвина, що продирався крізь принишклий натовп, згинаючись під тягарем кобзи [10, с. 57].

б) образна пам'ять, яка відображає минуле у формі переважно зорових, слухових, нюхових, смакових, дотикових мнемічних образів: Змигнуло у пам'яті й на серці стало тепло: ніде мені так добре $i$ солодко не спалося $i$ ніде не снилися такі гарні сни, як на нашій старій порепаній печі, що завжди пахла свіжим хлібом, грибами $і$ яблуками [10, с. 123]. Ще залишилися в пам'яті занедбані, потопаючі у глевкій грязі міста, похмурі й убогі «дєрєвні», курай $і$ бугила, щэо підступають до самих вікон, злиденні убогі обійстя, де ніколи не зустрінуть тебе привітно 
i гостинно, як у нас. Вічна нужда, смуток і недовіра. Непривітні темні, завжди спідлоба, погляди мужиків $i$ мат або свист у спину, як ніжс [11, с. 101]; Пригадалося дитинство у Галичині. Наша старенька приземкувата, але завжди чепурна хатка тулилася край дороги, під пагорбом, ніби ховалася од людського ока у кущчах бозу. Я любив сидіти у тих кущзах і спостерігати за рухом на дорозі. Хто їхав волами, ліниво погейкуючи на круторогих, хто кіньми, хто чимчикував пішки...На мене рідко звертали увагу. Тільки один Карпо Волох завюди підморгував мені, кидав якісь жсартівливі фрази, а іноді щось дарував... Карпові було уже, либонь, за двадиять, він щзойно повернувся з Січі, ходив з ціпом, од нього завжсд пахло пшеничним полем [11, с. 54]; Заплющу очі й ніби в полусниві бачу малинові илики - широкі розлиті хвилі, щзо котяться степом. I вільна пісня, як лет вірлюка [11, с. 19]. Мнемічні образи зазнають впливу з боку інших уявлень, процесів збереження і забування, а тому характеризуються як мінливі образи реальності.

Предикати пам'яті є показовими для ЩД і вживаються найбільш послідовно. Вони функціонують у його поверхневій структурі як мовленнєві виявлення на лексичному рівні основних процесів пам'яті (запам'ятовування, збереження, відтворення, забування) 3 відповідним значенням. Розглянемо особливості функціонування цих предикатів:

a) Предикат пам'ятати, має значення «тримати в пам'яті (у виразному, активному полі свідомості) будь-які знання, навички, уміння, мати можливість завжди реалізувати їх на практиці» [2, с. 166], виражає не тільки процес збереження інформації: Дивлюсь на нього $i$ згадую відвідини Китаю в ранній ранок його нового життя, коли народи наші поставали в дружбі, щуо їй, здавалось, ніколи не минати... ... $і$ ми згадуєм славного Мао Дуня, з яким ми заприязнились; згадуються інші люди, культурні, освічені, до яких я так $i$ не міг в роки чвар відчути ворожості... [3, т. 3, с. 67], але і безпосередньо процес пригадування, чи відтворення інформації: згадую як колись: Але де брати сил відбиватися від негідників? У Миколаєві, пишуть, уночі знесли пам'ятник Шевченкові. Як колись у 1937-му в Харкові «вкрадено» було погруддя Блакитного. Пригадую - ̈̈демо на навчання, а в скверику пусто [3, т. 3, с. 69].

Натомість процес відтворення інформації виражається у ЩД дієсловом згадувати: Бачу схвильованість колишніх фронтовиків, схвильований $і$ сам, бо згадались ті, може, найщасливіші дні у житті, травневі дні 1945-го під Прагою, коли сонце Перемоги так сліпучо засяяло, і стало враз тихо над Європою, і тиша та для нас була - як найкращуа в світі музика [3, т. 3, с. 19] або Вони згадували про нього як про косаря доброго, щзо, укосивщи багато сінокосу, ліг надовго відпочити. Згадували про людей головним чином у плані їхніх робочих здібностей [4, с. 240]. Згадувати можна любити: Про батька Іван Степанович навпаки любив згадувати $і$ незмінно висловлювався з великим пієтетом... [11, с. 79] i 
навпаки не любити, не хотіти: Мазепа не любив згадувати своє минуле, навіть коли був у доброму настрої і перебував у приємному товаристві [11, с. 78]; Тепер, на схилі віку, я більще не хочу ні думати, ні згадувати про неї, хоча за молодих літ вважав себе сином війни і не уявляв свого життя без кривавих січей $[11$, с. 11].

Цей процес може викликати в суб'єкта, який згадує, певні почуття й емоції. У ЩД для експлікації таких емоцій і почуттів з дієсловом згадувати використовується обставини образу дії, на зразок ніжно, із задоволенням, з вдячністю, з сумом тощо: Всеволод Попов, росіянин-москвич, розповідав мені з сумом, що під Мелітополем на фронті він був свідком явищ глибоко обурливих і огидних. Він бачив, як наші визволителі нищили дівчат, щзо мали чи й не мали нещастя побути під німиями [4, с. 308]; або вживається додаток, на зразок згадати словом вдячності: Готую слово до Наради україністів-перекладачів із соиіалістичних республік. Що їм сказати, коли вони все знають? Хіба що згадаю словом вдячності добрих людей, що зустрічались на життєвім шляху. Таких, як Рудольф Гулка, чех, мій перший перекладач... Ось $і$ змигнуло життя. Скількох уже більше не зустрінеш, тільки скажеш: були, були... [3, т. 3, с. 19].

б) Дісслово нагадувати, пригадувати у «Великому тлумачному словнику сучасної української мови» має значення «1. nерех. і неперех. Примушувати згадати про кого-, що-небудь. 3. Відновляти в пам'яті минулі події, явища, образи і т. ін.; згадувати» [1, с. 554], протиставляється дієслову згадувати по семі «каузативність» - «1. відтворювати у пам'яті, свідомості, події, обставини, образи і т. ін. минулого, відновлювати уявлення про кого-, що-небудь» [1, с. 357]. Як правило, пригадувати я намагаюся, хочу: Нарешті такий довгий $і$ багатий на зустрічі та події день, щзо пізнім вечором намагаюся пригадати: ие було вчора чи сьогодні вранці? [8, с. 47]; Пригадую, що за тиждень - Великдень і стає жаль, щео не дотягую иі кілька днів, коли відкриті небеса [8, с. 49]; Пригадується, иарська армія билася краще. Була кращза дисципліна, кращза виучка і було ще щось вічне, високе, всім дороге $i$ доступне - віра $i$ батьківщина...[4, с. 261]; Пригадую, що років двадиять тому мені потрапив до рук щуоденник одного письменника, який основну увагу зосередив на описах своїх недуг $i$ боротьби з ними, іншими словами кажучи, ие була книга про страждання тіла і емпіреї духу [8, с. 49].

в) Значення «закріпити у пам'яті результати почуттєвої i мисленнєвої діяльності свідомості (результати пізнання)» [2, с. 167] вирізняється 3-поміж ядерного значення предиката пам'ятати семою становлення і виражається дієсловом запам'ятати: Запам'ятай собi. Німиі - мериі. Мериі і ті, хто з ними свідомо чи несвідомо [4, с. 199].

Психологи відзначають, що залежно від способу й характеру здійснення процесів пам'яті існує дві форми запам'ятовування мимовільне й немимовільне. Під час останнього завжди ставиться завдання 
- запам'ятати, тобто здійснюється спеціальна мнемічна, специфічно людська форма діяльності. Цей вид запам'ятовування є показовим через функціонування в тексті своєрідних мовних ланцюжків на зразок:

а) маемо пам'ятати: Маемо пам'ятати: якби Господь хотів, то всіх поставив би на коліна, але Він, очевидно, хоче, щуоб наша любов, подив, $i$ замилування Божим світом, зігнули наші коліна ... [9, с. 9];

б) треба пам'ятати: I щзе треба пам'ятати: хто щзасливий, той вразливий. Бо не щзастя - високий дар цуього світу, а спокій, душевна рівновага, лагідний лад душі ...[9, с. 21];

в) збережіть, нікому не повідайте: Ви ж мене любили, як ніхто, леліяли, оберігали. Та і Ви збережіть таємницюю, нікому ї не повідайте $[11$, c. 28];

г) пам'ятайте: - Я мало зробив у літературі, - скаржиться Олекса Гай-Головко, - але пам'ятайте, мені завжди доводилось багато працюювати, і я писав тільки у вихідні й ночами [10, с. 54];

г) згадай: Згадай хоча б Олександра Меня [9, с. 32];

д) Не хочеться пам'ятати: Не хочеться пам'ятати про свій вік-як добре, шуо носять ноги, пишуться книги і шее багнеться жити $[9$, c. 60];

е) воліс не згадувати: Про сина воліє не згадувати, коли ж хто ненароком прохопиться, ї̈ лище перекошує страшна гримаса болю $[11$, c. 76];

є) постарайся запам'ятати або не забувати б: ...в зрілі роки приходить усвідомлення спільної провини. Ось про цуе не забувати б [9, с. 61] тощо.

Під час немимовільного запам'ятовування в мовних конструкціях, які використовує той, хто згадує, зазначається мета, що зумовлює основну дію: Смерть не усміхнулася йому. Вона пройшла мимо, не глянувши на нього своїм невблаганним оком. Вона тільки мимохідь доторкнулася до нього, щцоб не забув він ії ніколи, ні на хвилинку, щзоб кликав ії в розпачі $i$ шукав ї̈ очима... [4, с. 267]. Досить активно автор ЩД вживає спонукальні (імперативні) речення, які виражають волю або намагання мовця спонукати співрозмовника до якоїсь дії, наприклад, забути чи не забути: Не певен, щзо згадаю всі його дивацтва, бо їх було багато, але хіба можнн забути поета, щзо взимку ходить у майці, трусах і рукавицях, молиться Будді й при кожній слушній нагоді нагадує, щзо в попередньому житті служив у війську Наполеона, дружив зі Стендалем $і$ був смертельно поранений під Москвою? [9, с. 109].

Мимовільне ж запам'ятовування відбувається без спеціально поставленої мети - запам'ятати, не прикладаючи вольових зусиль. Воно становить особливий інтерес у нашому дослідженні. Форма мимовільного запам'ятовування реалізується у мові через зворотній корелят дієслова запам'ятати - запам'ятовуватись: Зустрічали старий Новий рік у 
Драчів. Славне було товариство, назавжди запам'ятається ия новорічна ніч [3, т. 3, с. 7]. В українському ЩД найактивніше мимовільно запам'ятовуються:

a) незвичайні події, образи, люди, які збуджують уяву своєю нестандартністю, жахливістю, значеннєвістю: Тринадиятого січня сорок другого року в тридиятиградусний мороз - у Києві на Подолі було оце $\boldsymbol{i}$ ніколи не вернеться - вели по вулиці з тюрми роздягнених, в одних трусах, $i$ босих, у кайданах сто чоловік матросів на розстріл через увесь Київ [4, с. 247]; В мойй уяві вона залишається красунею - блондинкою $з$ блакитними очима [8, с. 18]; Батько Іван на схилі віку боявся не так смерті, як того, що робитиме на небі, де нема ні землі, ні плуга. Потім я завжди, коли ходив за плугом, то чув не вітер у себе за спиною, а важкий подих батька [11, с. 43]

б) подразники, які є важливими для певного індивіда (наприклад, професійно значеннєві предмети): Щоденник М. Пришвина вперше потрапив мені до рук десь у дванадиятилітньому віиі. Тоді я не зміг його осилити, він не відкрився мені у всій свойй глибині й силі, але товстий томик у зелених иупких палітурках залишив у душі якесь особливо чисте і яскраве світло. Це змушує мене задумуватися над магією письма та імені. Чомусь я постійно носив у пам'яті ту книжку, хоч повернувся до неї тільки через два десятиліття, - повернувся, щоб більше ніколи не розлучатися [10, с. 118]; Натрапив на згадку в критииі про «Стокозове поле»... Коли (десь, мабуть, року 1936-го) я послав ияю повість на відгук Панчеві, він відповів, щзо ие найсильніша річ з усієї сучасної української літератури. Але... друкувати, мовляв, ніхто не візьме. Бо голод. На матеріалі Сухої - вся трагедія 1933 року. Так було. Пам'ятаю, як багато було осінньої туги. А всі доробки - то було самознищення [3, т. 3, с. 62]; Вхід у яскиню, а перед ним розмитий, ледь окреслений силует колінкую чого чения, обабіч дерева, рвані вітрами, переплетені крони, лет листя, $і$ в тій круговерті, у мерехтінні, грі світла і темряви - принишклі будиночки, щзо ніби виринають з минулого століття. Все летить $і$ міниться, тужить $i$ зітхає ... Такий зміст картини Ганни Ткачик «Пам'яті навперейми» $[8$, с. 196$]$;

в) подразники з особливим емоційним забарвленням: $У$ изих стислих замальовках, фрагментарних спогадах стільки світла, душевної краси $і$ емоційної напруги, щзо все постмодерне чтиво поряд з ними міліє й ниціє на очах, виявляючи його мізерність $і$ ніщету [9, с. 179]; Я пригадав, як ішли вони, як проносився цей ураган по Свропі, як падали держави, культури, нації. Як поверзлась Свропа в безодню безправ'я, виродження $i$ жалюгідного животіння. Вся земля тремтіла... [4, с. 249].

Пам'ятати протиставляється пригадувати на підставі опозиції «мати знання про минуле / його набуття в акті «спогади», які залежать від свідомих зусиль суб'єкта» [6, с. 46]. Процес пригадування, представляється 
нам як процес відтворення у пам'яті: Подзвонив П. Загребельний. Вітав. Згадав літа молодості [3, т. 3, с. 41]; Пригадую, якось говорили Братковський з Мазепою про політику [11, с. 126]; Погуляв я ичими степами - є щцо пригадати [11, с. 77]; Хто з мого покоління не пригадує індійських фільмів... [9, с. 194]; Сьогодні знову наснився Хміль $i$, прокинувшись, ще довго не міг вийти з того сновидіння. A потім пригадався бенкет у гетьмана [11, с. 19]. Окрім цього, процес пригадування пов'язаний з подоланням певних труднощів. Біля дієслова пригадувати в українському ЩД вживаються маркери намагайся пригадати, не можу згадати, важко пригадати, не пригадати тощо: Мені не пригадати миті, коли я появився на світ. Та їі пам'ятає душа. Мені не усвідомити миті, коли відійду. Та вона має багато важити для душі [11, с. 48]. I навпаки процес пригадування може пов'язуватися 3 приємними життєвими митями: Не без усмішки згадую: коли мені було двадиять, я мав переконання, щзо найважче помирати молодим [9, с. 30].

Ступінь активності суб'єкта, який згадує минуле, неоднакова. У ЩД вона знаходить своє вираження через вживання синонімічних і одночасно опозиційних синтаксичних конструкцій, які охоплюють одиниці аксіологічного поля «пам'ять»: я пам'ятаю - згадується, пригадується, пам'ятасться. У таких безособових реченнях і складних конструкціях, в яких у синтаксичній ролі підмета виступає назва пригадуваної події, підкреслюється пасивність суб'єкта, який згадує, i одночасно невимушеність, підсвідомість: $A$ мені згадалось: Грузія. Святкуємо Руставелі на його батьківщині... [3, т. 3, с. 41]; Пригадалось: Прага, відкривається з '̈зд письменників, обирають президію, один по одному названі виходять на сцену. Ось названо словацьку письменницю, вона весела така молодичка, типова словачка - сидить з друзями якраз навпроти нас у залі. Коли ведучий здивовано звернувся до неї: просимо, мовляв, - вона, засміявшись, крутнула головою: - Не хщем! [3, т. 3, с. 32]; ...Кунцево, де я в 1977 вишкрябувавсь після інсульту до життя, було колись велике село, в наполеонівські часи тут франиузиків шарпали бородаті кріпаки-партизани, а в 1941 через Кунцево йили на фронт дивізії москов. ополчення ( $і$ геній в обмотках), а на кунцевських дачах свого часу бували Карамзін, Тургенєв, Лев Толстой... [3, т. 3, с. 35].

Антонімічним до дієслова пам'ятати є значення - забути, забувати. Воно становить лексичний опозиційний ланцюжок пам'ятати - забувати. Мовленнєвими маркерами цього процесу $\epsilon$ вживання поряд 3 цими дієсловами пояснення на зразок: I раптом $я$ просіяв. Гордість і радість наповнили мене. І я побачив у вас героїв. Тоді я забув про все на світі, про смерть і про свою рану, про бомби і міни. Я встав і крикнув вам. Я зрозумів [4, с. 251]; Дурість моя в тім, щзо я весь час забував, що більшість міських людей - цуе дурні і убогенькі [4, с. 263]. 
Предикати пам'яті, які означають збереження інформації чи іiі втрату, характеризуються, як правило, часовими показниками до цього часу, досі, сьогодні, вчора, завжди як зараз, уже, чомусь, які свідчать про те, що з часом з будь-яких суб'єктивних причин спогади можуть або зберігатися, або втрачатися, забуватися: Досі згадують дніпропетровизі ті кошмарні дні сваволі й тиску, залякувань та иькувань... Скільки чесних людей безневинно потерпіло за «Собор»! I скільки було руйначів, засліплених пристрастю браконьєрською, осоловілих від ненависті, здичавілих від розлюченості, жадаючих помсти...I тільки душам найсвітлішим, най далекогляднішим дано було зрозуміти, що «Собор» невмирущий [3, т. 3, с. 38]; Чомусь згадалося вночі [3, т. 3, с. 12]; Згадалось сьогодні, як Ліля і Леся виконували щзось із Моцар та на сопілках (нове й таке чудове їхнс захоплення) [3, т. 3, с. 34]; Завжди я пам'ятав, як прихильно поставився він [О. Корнійчук] до мене при виході «Альп» $[3$, т. 3 , с. 45$]$.

Дієслова пам'ятаю, згадую, пригадую окреслюють аксіологічне поля «пам'ять». До цих дієслів приєднуються підрядні з'ясувальні, які містять інформацію про факти, процеси, явища, а також $з$ імена, назви, дублюючи поєднувальність з дієсловами сприймання: Пригадується, як подарував він мені рядок вірша Маланюкового, сповнений туги: «Час, Господи, на самоту й покуту...» [3, т. 3, с. 56]; Сьогодні ранком мати розповідала, як умирав мій брат Андрійко. У нього з дитинства було порочне серие, $i$ він знав, що він не жилець на світі, про що не один раз казав $і$ матері... [4, с. 310]; ... щуойно подзвонила Олена Григорівна, розповіла, як у 1942-му, виступаючи по радіо, Довженко не міг втримати ридань, згадавши матір і Україну, - навіть довелося вимикати мікрофон, $i$ ще розповідала, як він хотів поставити собі хату в Кончі, близько того місия, де зараз знаходиться водонапірна башта... Але - не судилось... $[3$, т. 3 , с. 30].

У ЩД автор ніби викорчовує низку стилістичних прийомів, які направлені на зображення самого процесу спомину, (мовленнєві засоби, які відображають зв'язок пам'яті і сприймання, образні паралелі, які пов'язані з лексемами пам'ять, спогади , життя, час, минуле: Згадувати про молодість, про щастя молодості - це теж щастя [3, т. 3, с. 73]; Що залишилося у пам'яті? Може, нічого, крім сліпучого блиску сонця $i$ відчуття свободи, яке через рік уже й не згадати [9, с. 55]; Слухаю враниі Тичину по радіо... Але, згадуючи попереднє життя поета, жахи, яких він набачився, багато щзо можна йому простити... [3, т. 3, с. 42]; Але вже за моєї пам'яті стало «легше» $i$ «веселіме» [9, с. 58]; Мабуть, тільки Шура й тпам'ятає ией родовід... [3, т. 3, с. 39]; Скільки пам'ятаю, ластівки завжди жили у нашому хліві, й сприймалися нами як щось дуже дороге $i$ рідне [8, с. 59]; Багато дечого иүікавого розповів мені хлопчина з деталей життя, розпитуючи мене, як живуть люде в других краӥнах [4, с. 312]; 
На нашу думку, своєрідністю українського щоденникового дискурсу $\epsilon$ те, що основу для його створення становлять специфічні механізми людської пам'яті. Образна характеристика пам'яті у значенні лексем спомини, пригадування, згадка, пам'ять актуалізуються семи «закарбуватися «, «зберегтися «, «врізатися». Пам'ять набуває образності шляхом використання загальномовних метафор, наприклад, пам'ять пристрій для записування інформації, пам'ять - сховище тощо. Завдяки пам'яті автор ЩД отримує можливість оперувати здобутками свого мислення. С істини відомі, які начебто постійно жсивуь у нашому серці, ми пам'ятаємо ӥх, але на мить забуваємо в суєті буднів, під тиском життевих обставин. Та приходить час, коли знову згадуєш їх, зупиняєшся ошелешений $і$ відкривається перед тобою ввесь жах безодні... $[11$, с. 130]. Аксіологічне поле «пам'ять» репрезентоване своєрідними предикатами пам'яті, які характеризують різні аспекти процесу пригадування. Лексеми пам'ять i пригадування активно вживаються авторами ЩД. Отже, цей процес насамперед пов'язаний 3 осмисленням авторами ЩД феномену індивідуальної пам'яті. Вони не тільки передають явища дійсності, не тільки пропонують нам подієвий потік свого життя, але й коментують свою сповідь про минуле.

\section{Література}

1. Великий тлумачний словник сучасної української мови / [уклад. і голов. ред. В. Т. Бусел]. - К. ; Ірпінь : ВТФ «Перун», 2004. - С. 540.

2. Васильев Л. М. Семантика русского глагола / Л. М. Васильев. - М. : Высшая школа, 1981. - 184 с.

3. Гончар О. Щоденники : у 3-х т. / О. Т. Гончар; [Упоряд., підгот. текстів, ілюстр. матеріалу В. Д. Гончар]. - К. : Веселка, 2002 -2004. - Т. 1 (1943-1967). 2002. - 455 с. Т.2 (1968-1983). 2003. - 607 с. Т.3 (1984-1995) 2004. - 606 c.

4. Довженко О. Вибрані твори / Упорядк. текстів та передм. І. Л. Михайлина. - Харків : Веста : Видавництво «Ранок», 2003. - 320 с.

5. Любченко А. П. Вертеп (повість). Оповідання. Щоденник / Упоряд., авт. післямов. В. А. Любченко; авт. передм., комент., приміт. І. Л. Михайлин. - Х. : Основа, 2005. - 464 с.

6. Ніколіна Н. А. Поэтика автобиографической прозы / Н. А. Николина. - М.: Флінта, 2002. - 424 с.

7. Селіванова О. О. Лінгвістична енциклопедія / О. О. Селіванова. - Полтава : Довкілля. - К., 2010. -844 с.

8. Сорока П. Денники 2004-2005 років / П. Сорока. - Тернопіль : СОРОКА, 2006. - 364 с.

9. Сорока П. Застиглий вогонь. Денники 2006 року / П. Сорока. - Тернопіль : СорокА, 2007. - 246 с.

10. Сорока П. Рік подвійних райдуг. Денники 2002 року / П. Сорока. - Тернопіль : Джура, 2003. - 132 с.

11. Сорока П. Душа при свічці (Діяріюш Федора Жученка) / П. Сорока. - Тернопіль : Джура, 2002. - 160 с. 